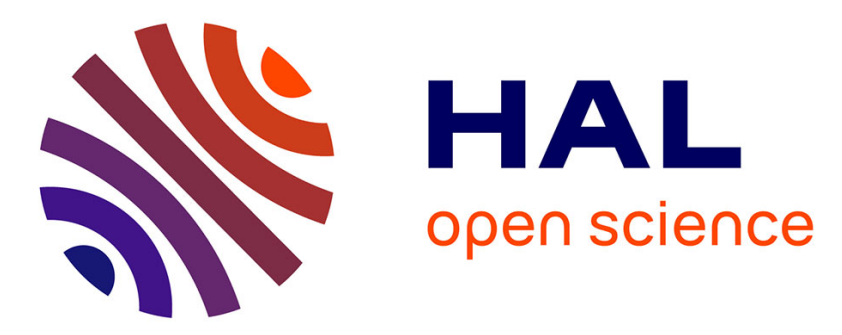

\title{
Summary of studies on hot corrosion of iron-based alloys by sodium sulfate in $\mathrm{O} 2 / \mathrm{SO} 2 / \mathrm{SO} 3$ environment
}

\author{
Yunshu Zhang, Weitao Wu
}

\section{To cite this version:}

Yunshu Zhang, Weitao Wu. Summary of studies on hot corrosion of iron-based alloys by sodium sulfate in O2/SO2/SO3 environment. Journal de Physique IV Proceedings, 1993, 03 (C9), pp.C9-319-C9-326. 10.1051/jp4:1993931 . jpa-00252369

\section{HAL Id: jpa-00252369 https://hal.science/jpa-00252369}

Submitted on 1 Jan 1993

HAL is a multi-disciplinary open access archive for the deposit and dissemination of scientific research documents, whether they are published or not. The documents may come from teaching and research institutions in France or abroad, or from public or private research centers.
L'archive ouverte pluridisciplinaire HAL, est destinée au dépôt et à la diffusion de documents scientifiques de niveau recherche, publiés ou non, émanant des établissements d'enseignement et de recherche français ou étrangers, des laboratoires publics ou privés. 


\title{
Summary of studies on hot corrosion of iron-based alloys by sodium sulfate in $\mathrm{O}_{2} / \mathrm{SO}_{2} / \mathrm{SO}_{3}$ environment (*)
}

\author{
Yunshu Zhang $\left({ }^{1}\right)$ and Weitao Wu $\left({ }^{2}\right)$ \\ (1) Shanghai Institute of Metallurgy, Academia Sinica, Shanghai 200050, China \\ $\left({ }^{2}\right)$ Institute of Corrosion and Protection of Metals, Academia Sinica, Shenyang 110015, China
}

\begin{abstract}
Iron base heat-resistant alloys are widely used in high temperature environments, especially in civil and industrial boilers and other combustors. This type of alloys was found to undergo hot corrosion when covered with a sulfate deposit. Recent studies of sulfate-depositinduced hot corrosion of iron-base alloys are selectively reviewed in this paper. Emphasis is placed on studies of the hot corrosion occurring at relatively low temperatures, concerning the thermodynamics of the formation of liquid sulfate eutectics, the corrosion behavior of various iron-base alloys, and an electrochemical mechanism proposed by the present authors. In addition, electrochemical measurements for the evaluation of hot corrosion resistance of iron-base alloys are briefly reported. Some coatings were prepared and their performance in hot corrosion environments is included in this paper.
\end{abstract}

\section{Introduction.}

As a type of high temperature alloy, iron-base heat-resistant alloys are extensively used in high temperature environments, especially in civil and industrial boilers and other combustors. The resistance of these alloys to sulfate-deposit-induced hot corrosion is of particular importance for the reliability of various components during operation. Early in this century, the occurrence of hot corrosion instances became known for ferrous-base boiler tubes in some power stations [1, 2]. A case of extensive wastage of 25/20 $\mathrm{Cr}-\mathrm{Ni}$ steel super-heater supports was found to be associated with a whitish $\mathrm{Na}_{2} \mathrm{SO}_{4}$-rich deposit [3]. Thereafter, investigations were undertaken to evaluate fireside deposit-induced hot corrosion behavior of iron base alloys [4]. However, all the work done was not as extensive as that for nickel- and cobalt-base alloys. In the past few years, hot corrosion of iron-base alloys has gained much attention, and extensive studies have been conducted towards the understanding of hot corrosion mechanisms. In this paper, recent progress in studies of hot corrosion of iron-base alloys are summarized, with emphasis on hot corrosion occurring at relatively low temperatures.

\section{High temperature hot corrosion of iron base alloys.}

Trafford and Whittle [5] examined the effect of $\mathrm{Na}_{2} \mathrm{SO}_{4}$ coatings on the oxidation behavior of pure iron and $\mathrm{Fe}-\mathrm{Cr}$ alloys in $1 \mathrm{~atm}$ oxygen at $900^{\circ} \mathrm{C}$. The oxidation behavior of pure iron was relatively unaffected while $\mathrm{Na}_{2} \mathrm{SO}_{4}$ coatings remarkably enhanced the oxidation rates of

(*) Keynote lecture. 
the Fe-Cr alloys, and thick, compact stratified oxide scales were formed, with sulfide particles in the alloy substrate. Because of the absence of a porous scale, a sulfide formation/cracking mechanism was proposed for the alloys. A hot corrosion reaction for $\mathrm{Na}_{2} \mathrm{SO}_{4}$-coated $\mathrm{Fe}-18 \mathrm{Cr}$ alloy was described. Initial exposure of the $\mathrm{Na}_{2} \mathrm{SO}_{4}$-coated alloy resulted in the formation of a Fe-containing $\mathrm{Cr}_{2} \mathrm{O}_{3}$ layer. The oxidation reaction required more oxygen than could be transported through the salt film, thus the local oxygen activity decreased. Because of this, the sulfur activity in the salt became sufficient for reaction between sulfur and the alloy, leading to the formation of discrete sulfide particles in the alloy substrate. Mechanical failure of the scale did occur and a continuous protective Cr-rich oxide layer was unable to form as a result of the depletion in $\mathrm{Cr}$ due to sulfide formation, thus breakaway oxidation took place.

Shi $e t$ al. [6] studied the oxidation of commercial iron and $\mathrm{Fe}-\mathrm{Cr}$ alloys in the presence of $\mathrm{Na}_{2} \mathrm{SO}_{4}-0.40 \mathrm{MgSO}_{4}-0.07 \mathrm{CaSO}_{4}$ salt coatings in an $\mathrm{O}_{2}-0.1 \%\left(\mathrm{SO}_{2}+\mathrm{SO}_{3}\right)$ gas atmosphere at $675-800{ }^{\circ} \mathrm{C}$ and found that all the materials tested underwent accelerated oxidation. Commercial iron and $\mathrm{Fe}-5 \mathrm{Cr}$ alloy were subject to uniform corrosion and a compact oxide scale was formed on either surface with massive sulfide particles within the scale and a sulfide band at the metal/scale interface. In contrast, $\mathrm{Fe}-10 \mathrm{Cr}$ and $\mathrm{Fe}-20 \mathrm{Cr}$ alloys were attacked locally to form a salt-containing Fe-rich oxide nodule with a rather thick $\mathrm{Cr}$ sulfide band underneath. Generally, the alloys were covered by a Cr-rich oxide layer. In the absence of a porous scale, an electrochemical mechanism was postulated to illustrate hot corrosion process. Sulfurcontaining species, in either gaseous or liquid form, could penetrate the oxide scale through pores and cracks, especially during mechanical failure of the scale. If these species were reduced, metal sulfides would be formed. For commercial iron and Fe-5Cr alloys, hot corrosion was attributed to the easier anodic process caused by sulfides, while for $\mathrm{Fe}-10 \mathrm{Cr}$ and $\mathrm{Fe}-20 \mathrm{Cr}$ alloys, accelerated kinetics were believed to result from the rapid anodic oxidation reaction of the base metal in the locations covered by Cr-rich sulfides.

Wu et al. [7] tested the corrosion resistance of various $\mathrm{Fe}-\mathrm{Cr}$ alloys in a $(\mathrm{Na} / \mathrm{K})_{2} \mathrm{SO}_{4}-25 \%$ $\mathrm{NaCl}$ melt in air at $800^{\circ} \mathrm{C}$, and found compact scales formed on the alloy surfaces, with hardly any porous oxides. Using an electrochemical technique combined with acoustic emission (AE), the authors monitored the hot corrosion of FeAl, FeAlZr and Fe-25Cr alloys in the same condition [8]. Sharp electrode potential drops were recorded repeatedly, with strong $\mathrm{AE}$ signals corresponding to each potential drop obtained. In the potentiostatic polarization conditions, as for $\mathrm{Fe}-25 \mathrm{Cr}$ alloy, either anodic or cathodic current peaks appeared frequently and, correspondingly, AE signals were also observed. These results clearly indicated that cracking of the protective oxide scales of the alloys did occur all the time during corrosion.

It is conceivable that oxide cracking may play an important, even a key role in hot corrosion, as oxide cracking would give rise to a condition leading to active dissolution of the metal and sulfide formation that results in degradation of the protective oxide scale. In the authors' opinion, hot corrosion of iron-base alloys may be better understood on the basis of an electrochemical mechanism in which the role played by oxide cracking is included.

For hot corrosion protection, a surface applied $\mathrm{CeO}_{2}$ coating combined with preoxidation on a HK 40 alloy [9] and laser remelt gas flame sprayed NiCrAl coating on 304 steel [10] were tested in $(\mathrm{Na} / \mathrm{K})_{2} \mathrm{SO}_{4}-\mathrm{NaCl}$ and $\mathrm{Na}_{2} \mathrm{SO}_{4}-\mathrm{V}_{2} \mathrm{O}_{5}$ melts, respectively. The coatings offered superior corrosion resistance, which was attributed to the formation of a continuous, dense, small grain size $\mathrm{Cr}_{2} \mathrm{O}_{3}$ or $\mathrm{Al}_{2} \mathrm{O}_{3}$ oxide layer, most probably with a low level of growth stress. 


\section{Hot corrosion occurring at relatively low temperatures.}

Because hot corrosion occurring at relatively low temperatures is related to the formation of liquid complex sulfates, a thermodynamic study on molten $\mathrm{Na}_{2} \mathrm{SO}_{4}-\mathrm{Fe}_{2}\left(\mathrm{SO}_{4}\right)_{3}$ and $\mathrm{Na}_{2} \mathrm{SO}_{4}$ $\mathrm{K}_{2} \mathrm{SO}_{4}-\mathrm{Fe}_{2}\left(\mathrm{SO}_{4}\right)_{3}$ systems was carried out [11]. By means of a regular solution approximation and a modified Temkin mixing model as well as molar fractions of $\mathrm{Fe}_{2}\left(\mathrm{SO}_{4}\right)_{3}$ in molten $\mathrm{Na}_{2} \mathrm{SO}_{4}-\mathrm{Fe}_{2}\left(\mathrm{SO}_{4}\right)_{3}$ determined experimentally, the critical partial pressures of $\mathrm{SO}_{3}$ required for the liquid sulfate formation were estimated with the help of the $\mathrm{Na}_{2} \mathrm{SO}_{4}-\mathrm{Fe}_{2}\left(\mathrm{SO}_{4}\right)_{3}$ phase diagram. Due to a lack of necessary thermodynamic data, the critical partial pressures of $\mathrm{SO}_{3}$ required for the formation of molten $\mathrm{Na}_{2} \mathrm{SO}_{4}-\mathrm{K}_{2} \mathrm{SO}_{4}-\mathrm{Fe}_{2}\left(\mathrm{SO}_{4}\right)_{3}$ were determined experimentally. The calculated results are shown in figure 1.

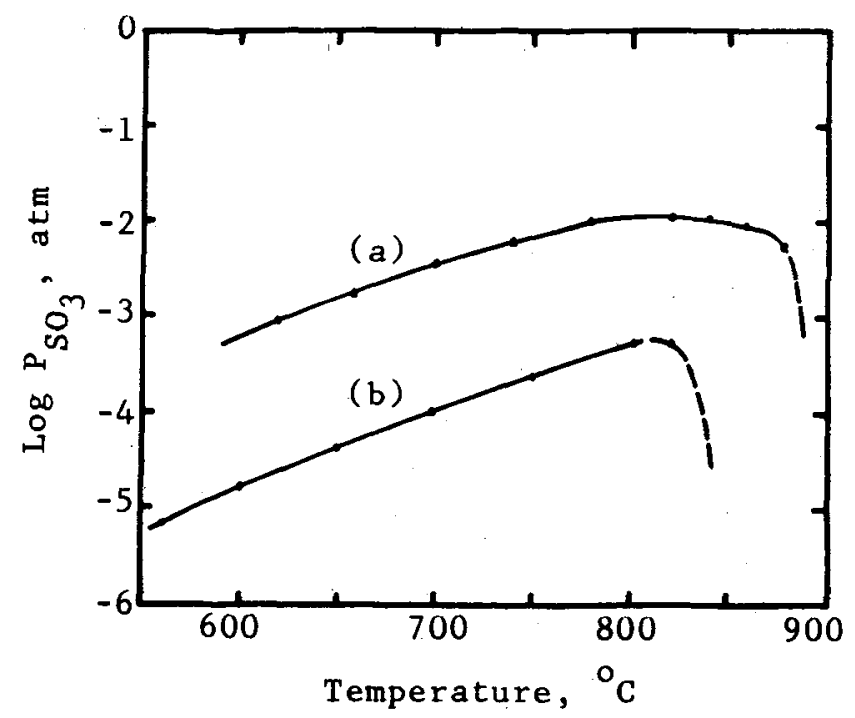

Fig. 1. - Estimated critical $P_{\mathrm{SO}_{3}}$ for the formation of molten $\mathrm{Na}_{2} \mathrm{SO}_{4}-\mathrm{Fe}_{2}\left(\mathrm{SO}_{4}\right)_{3}$ (a) and $\mathrm{Na}_{2} \mathrm{SO}_{4}$ $\mathrm{K}_{2} \mathrm{SO}_{4}-\mathrm{Fe}_{2}\left(\mathrm{SO}_{4}\right)_{3}(\mathrm{~b})$.

The hot corrosion behavior of commercial iron, and $\mathrm{Fe}-\mathrm{Cr}$ alloys with 5,10 and $20 \% \mathrm{Cr}$, and $\mathrm{Fe}$-Al alloys with 5 and $10 \% \mathrm{Al}$, was studied in the presence of a $\mathrm{Na}_{2} \mathrm{SO}_{4}$ deposit in 1 atm $\mathrm{O}_{2}-0.1,0.5$ and $1.0 \mathrm{vol} . \%\left(\mathrm{SO}_{2}+\mathrm{SO}_{3}\right)$ gas atmospheres at $650-750{ }^{\circ} \mathrm{C}[12,13]$. The effect of surface $\mathrm{K}_{2} \mathrm{SO}_{4}-\mathrm{Na}_{2} \mathrm{SO}_{4}$ coatings on the hot corrosion behavior of commercial iron, Fe-Cr alloys containing up to $50 \% \mathrm{Cr}, 304$ steel and the FeAl intermetallic compound was also studied in the same gas environments at $560-750^{\circ} \mathrm{C}$ [14-16]. All the materials tested were found to suffer from hot corrosion in the experimental conditions with evidence of complex sulfate eutectic melt formation. For commercial iron and the Fe-5 $\mathrm{Cr}$ alloy, the corrosion product scale consisted of a porous $\mathrm{Fe}_{2} \mathrm{O}_{3}$ plus salt layer, and a compact oxide layer with metal sulfides beneath it. The corrosion morphology of the other alloys was similar to that for commercial iron and the $\mathrm{Fe}-5 \mathrm{Cr}$ alloy except that the inner, compact corrosion product layer was composed of $\mathrm{Cr}$ or $\mathrm{Al}$-rich oxides with substantially $\mathrm{Fe}_{2} \mathrm{O}_{3}$ on their surface and a $\mathrm{Cr}$ or Al-rich sulfide band at the alloy/scale interface. The hot corrosion process for each 
material could be divided into two stages. A relatively high rate of weight-gain was observed at the initial stage, and various reactions were involved, including metal oxidation, sulfation of the base metal oxide, and formation of a liquid sulfate eutectic. At steady-state both porous and compact corrosion product layers grew at the same time, essentially at a parabolic rate.

Corrosion kinetics were found to be dependent upon temperature, gas composition, alloying element content and salt deposit composition. For commercial iron, the corrosion rate increased monotonously with temperature while for the alloys, maximum corrosion rates occurred in an intermediate temperature range, i.e., around $650-700^{\circ} \mathrm{C}$ which varied with the alloy element content, as shown in figure 2 for $\mathrm{K}_{2} \mathrm{SO}_{4}-\mathrm{Na}_{2} \mathrm{SO}_{4}$ coated $\mathrm{Fe}-\mathrm{Cr}$ alloys corroded in a $\mathrm{O}_{2}-0.5 \%\left(\mathrm{SO}_{2}+\mathrm{SO}_{3}\right)$ gas atmosphere for a duration of 24 hours. In general, the higher the $P_{\mathrm{SO}_{3}}$ in the gas atmosphere, the more severe the corrosion. The beneficial effect of alloy additions of both $\mathrm{Cr}$ and $\mathrm{Al}$ were shown in the corrosion tests, although an aluminum addition, even an aluminide coating, failed to eliminate hot corrosion of alloys due to the sulfation of $\mathrm{Al}_{2} \mathrm{O}_{3}$, as indicated below. The addition of either $\mathrm{K}_{2} \mathrm{SO}_{4}$ to a $\mathrm{Na}_{2} \mathrm{SO}_{4}$ deposit or $\mathrm{Na}_{2} \mathrm{SO}_{4}$ to a $\mathrm{K}_{2} \mathrm{SO}_{4}$ deposit brought about an enhanced corrosion rate of iron-base alloys. This result was attributed to the earlier appearance of a ternary sulfate eutectic, $\mathrm{Na}_{2} \mathrm{SO}_{4}$ $\mathrm{K}_{2} \mathrm{SO}_{4}-\mathrm{Fe}_{2}\left(\mathrm{SO}_{4}\right)_{3}$, on the basis of the experimental evidence and a detailed thermodynamic analysis of the relevant phase equilibrium for sulfate mixtures.

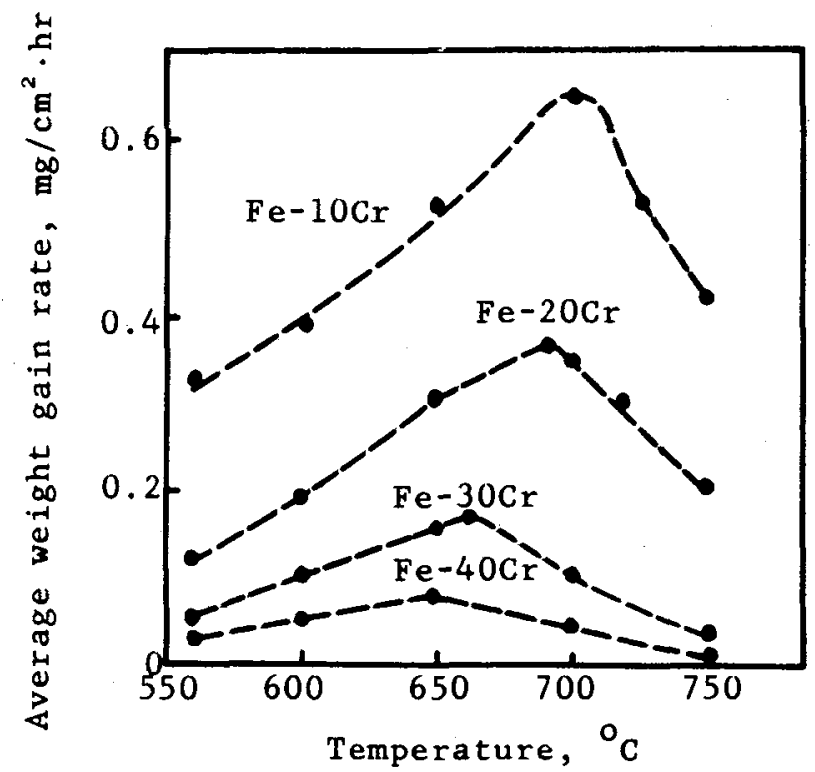

Fig. 2, - Temperature dependence of average corrosion rate for $\mathrm{K}_{2} \mathrm{SO}_{4}-\mathrm{Na}_{2} \mathrm{SO}_{4}$ coated $\mathrm{Fe}-\mathrm{Cr}$ alloys corroded in $\mathrm{O}_{2}-0.5 \%\left(\mathrm{SO}_{2}+\mathrm{SO}_{3}\right)$ gas atmosphere for $24 \mathrm{~h}$.

The hot corrosion process of iron-base alloys was at first explained with a fluxing mechanism similar to that for LTHC of cobalt-base alloys. Careful examinations of corrosion morphology made later, however, revealed some evidence in disagreement with the fluxing mechanism. Therefore, the authors proposed an electrochemical mechanism for iron-base alloys [17-18]. In hot corrosion, iron (including other metals) takes part in the anodic oxidation 
reaction to form $\mathrm{Fe}^{2+}$ ions, some of which are further oxidized to $\mathrm{Fe}^{3+}$ in the compact oxide layer. In the melt, $\mathrm{O}_{2}$ and $\mathrm{S}_{2} \mathrm{O}_{7}^{2-}$, mainly the latter, participate in the cathodic reaction on the surface of the compact oxide layer, and $\mathrm{O}^{2-}$ ions produced are incorporated into the oxide lattice and combined with $\mathrm{Fe}^{3+}$ to form $\mathrm{Fe}_{2} \mathrm{O}_{3}$. In such a way, the compact oxide layer grows. From the cathodic reaction, $\mathrm{SO}_{2}$, even $\mathrm{SO}_{4}^{2-}$, could penetrate the compact oxide layer through pores and cracks, thus leading to the formation of sulfides at the metal/oxide interface as well as within the oxide layer. The rapid growth of the compact oxide layer can be attributed to the easy diffusion of cations down short-circuit paths of sulfides. In the eutectic melt, $\mathrm{Fe}^{3+}$ ions may also take part in the cathodic reaction. The $\mathrm{Fe}^{2+}$ product ions and those from the anodic reaction and dissolved in the melt transport and get oxidized in the melt near the melt/gas interface, causing $\mathrm{Fe}_{2} \mathrm{O}_{3}$ particles to precipitate.

The study by Buscaglia et al. [19] is worth mentioning in which the experimental conditions are close to the real combustion atmospheres encountered in some coal-fired power plants. Accelerated oxidation of pure iron in the presence of a $\mathrm{Na}_{2} \mathrm{SO}_{4}$ deposit in a 1 atm $\mathrm{N}_{2}$ $3.6 \% \mathrm{O}_{2}-0.25 \% \mathrm{SO}_{2}$ gas environment was observed at $600-800{ }^{\circ} \mathrm{C}$. The partial pressures in the gas phase were lower than those required for the formation of a liquid $\mathrm{Na}_{2} \mathrm{SO}_{4}-\mathrm{Fe}_{2}\left(\mathrm{SO}_{4}\right)_{3}$ eutectic. From a reasonable thermodynamic calculation, a liquid sulfate phase, $\mathrm{Na}_{2} \mathrm{SO}_{4}-\mathrm{FeSO}_{4}$, was believed to form on the metal surface. This study implies that hot corrosion could occur in gas atmospheres with lower $P_{\mathrm{SO}_{3}}$ than the estimated values presented at the beginning of this section since $\mathrm{FeSO}_{4}$ may be involved in the complex liquid sulfate phase.

For hot corrosion protection, diffusion aluminized and chromized coatings on commercial iron were prepared, and their corrosion resistance was evaluated in the presence of a surface $\mathrm{K}_{2} \mathrm{SO}_{4}-\mathrm{Na}_{2} \mathrm{SO}_{4}$ deposit in 1 atm $\mathrm{O}_{2}-0.1,0.5$ and $1.0 \%\left(\mathrm{SO}_{2}+\mathrm{SO}_{3}\right)$ gas atmospheres at $560-750{ }^{\circ} \mathrm{C}$ [20]. Aluminized iron was found to be still subject to hot corrosion although its corrosion rate was significantly reduced. A liquid $\mathrm{K}_{2} \mathrm{SO}_{4}-\mathrm{Na}_{2} \mathrm{SO}_{4}-\mathrm{Al}_{2}\left(\mathrm{SO}_{4}\right)_{3}-\mathrm{Fe}_{2}\left(\mathrm{SO}_{4}\right)_{3}$ melt was believed to be responsible for the corrosion. Chromized iron exhibited excellent corrosion resistance, which was attributed to the rapid development of a continuous $\mathrm{Cr}_{2} \mathrm{O}_{3}$ layer on the coating surface. From these results, chromizing was an effective means for hot corrosion protection of iron-base alloys.

\section{Electrochemical studies of hot corrosion.}

Hot corrosion resistance of iron-base alloys has been tentatively evaluated by electrochemical measurements with the help of various techniques such as weak polarization, linear and differential polarization, and $\mathrm{AC}$ impedance.

A technique of weak polarization with computer-aided polarization curve fitting was developed by Zhang et al. [21, 22], which is suitable for the evaluation of the corrosion behavior of alloys and coatings in molten salts. Reactions on the corroding metal electrode in molten salts are quite different from those in aqueous solutions at ambient temperature. For the latter case, only one irreversible reaction is often assumed for either the cathodic or anodic process. However, for the electrochemical reactions in high-temperature molten salts, i.e., reversible or quasi-reversible reactions, converse reactions for both cathodic and anodic processes must be considered. The polarization equations in a complex form with more than five kinetic parameters were proposed together with a Basic program for finding optimum solutions. By using this technique, the polarization curve fitting for a number of iron-base alloys corroded in a $(\mathrm{Na} / \mathrm{K})_{2} \mathrm{SO}_{4}-25 \% \mathrm{NaCl}$ melt at $800^{\circ} \mathrm{C}$ was made, and their corrosion rates were calculated.

The hot corrosion behavior of various commercial iron-base alloys in $(\mathrm{Na} / \mathrm{K})_{2} \mathrm{SO}_{4}$ - 
$25 \% \mathrm{NaCl}$ melt at $800^{\circ} \mathrm{C}$ was evaluated by combined linear polarization resistance and corrosion potential measurements [23]. As shown in figure 3, the corrosion potential of 801 alloy with $20 \% \mathrm{Cr}$ and $32 \% \mathrm{Ni}$ changes with time in the more noble direction and, at the same time, an increase in $R_{\mathrm{p}}$ is observed. This implies that a compact, protective oxide layer is gradually formed on the alloy surface and, as a result, the alloy corrosion rate is reduced. For $\mathrm{Cr} 13$ alloy, both the corrosion potential and $R_{\mathrm{p}}$ begin to decrease after 8 hours of immersion in the melt. A potential fall followed by a potential rise appear repeatedly for this alloy, which is related to the cyclic cracking and rehealing of the oxide layer. The corrosion resistance of alloy 801 is superior to that of the Cr13 alloy. From the time-dependent corrosion potential and linear polarization resistance measurements, the improvement in hot corrosion resistance for the $\mathrm{HK} 40$ alloy by a surface applied $\mathrm{CeO}_{2}$ coating combined with preoxidation treatment was also demonstrated. These electrochemical measurement results are consistent with corrosion morphology examinations of the alloys. To overcome the difficulty encountered in linear polarization measurements, the differential polarization technique has been applied to hot corrosion resistance evaluation. For this purpose, $I_{\text {corr }}$ expressions were derived, again with converse reactions considered. Differential polarization resistance measurements were conducted on Fe-1.5 $\mathrm{Cr}$ alloy and 316 steel with and without $0.2 \%$ Ce addition in the same condition as mentioned above. The measured results were in excellent agreement with the linear polarization resistance values of the alloys.

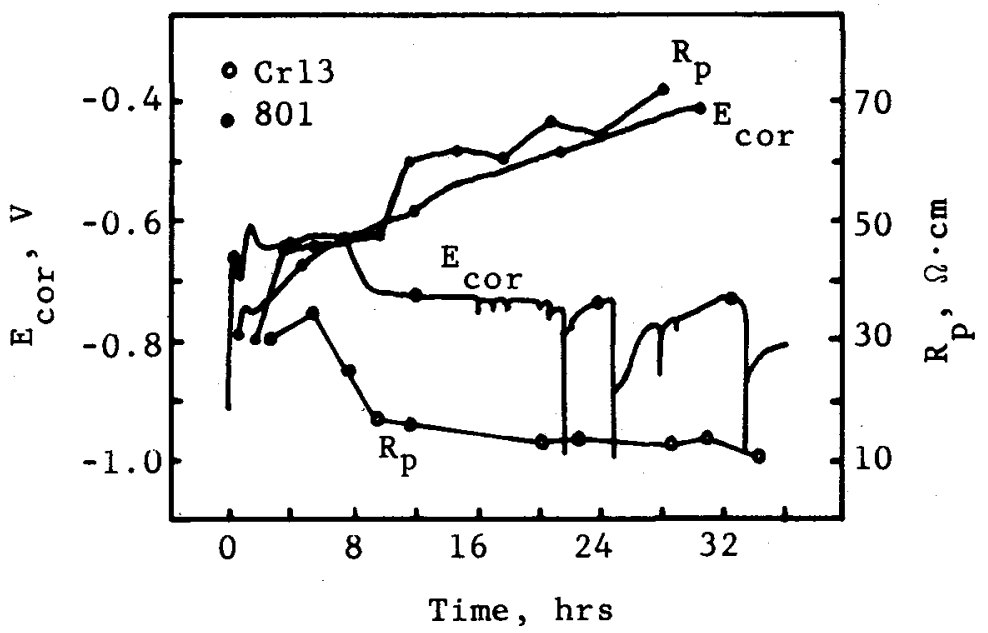

Fig. 3. - Time-dependent corrosion potential and linear polarization resistance of 801 and $\mathrm{Cr} 13$ alloys in $(\mathrm{Na} / \mathrm{K})_{2} \mathrm{SO}_{4}-25 \% \mathrm{NaCl}$ melt at $800^{\circ} \mathrm{C}$.

Wu et al. [24] conducted AC impedance measurements on a number of nickel- and ironbase alloys either in a $\mathrm{Na}_{2} \mathrm{SO}_{4}-0.5 \mathrm{Li}_{2} \mathrm{SO}_{4}$ melt at $973 \mathrm{~K}$ or in a $\mathrm{Na}_{2} \mathrm{SO}_{4}-0.3 \mathrm{NaCl}$ melt at $1073 \mathrm{~K}$ in the frequency range of $1 \mathrm{mHz}-100 \mathrm{kHz}$. A linear correlation between the polarization conductance $1 / R_{\mathrm{p}}$ obtained from $\mathrm{AC}$ impedance data at $10 \mathrm{mHz}$ and the corrosion current density from weight loss was established for the alloys in the alkali sulfate melts at $973 \mathrm{~K}$. The anodic polarization characteristics of the alloys correlated well with the corrosion resistance. $\mathrm{AC}$ impedance and voltammetry data showed that alloys with more than $15 \% \mathrm{Cr}$ had good 
corrosion resistance in the $\mathrm{Na}_{2} \mathrm{SO}_{4}-\mathrm{Li}_{2} \mathrm{SO}_{4}$ melt, whereas the breakdown of oxide films on the alloy surface was observed frequently in the $\mathrm{Na}_{2} \mathrm{SO}_{4}-\mathrm{NaCl}$ melt, even in the case of high Cr content alloys. These results have confirmed that it is possible to estimate corrosion rates of alloys by the AC impedance method.

Even though the electrochemical polarization in deep melts can produce hot corrosion fairly similar to that found due to a thin salt film in a combustion environment, electrochemical measurements on metals and alloys beneath a thin salt film in an oxidizing gas environment are necessary for the better correlation of hot corrosion kinetics between laboratory experiments and actual practice.

\section{Conclusions.}

From the results of recent studies on hot corrosion of iron-base alloys presented above, the following conclusions can be drawn:

1) Iron-base alloys were found to undergo hot corrosion at high temperatures when covered with a sulfate deposit. This phenomenon was related to the formation of sulfides and failure of oxide scales. According to the present authors, the hot corrosion may be better explained on the basis an electrochemical mechanism in which the role of oxide cracking is included.

2) Iron-base alloys were also found to be subject to sulfate-deposit-induced hot corrosion at relatively low temperatures in $\mathrm{O}_{2} / \mathrm{SO}_{2} / \mathrm{SO}_{3}$-containing environments. The hot corrosion was attributed to the formation of low-melting complex sulfate eutectics and illustrated with an electrochemical mechanism.

3) Electrochemical techniques such as weak polarization, linear and differential polarization, and $\mathrm{AC}$ impedance were used to evaluate hot corrosion resistance, and promising results have been obtained.

\section{Acknowledgements.}

The National Natural Science Foundation of China and Corrosion Science Laboratory of Academia Sinica are acknowledged for their support for the studies on hot corrosion, some results of which are presented in this paper.

\section{References}

[1] ReID W.T., CoReY R.C., Cross B.J., Trans. ASME 67 (1945) 279-289.

[2] Nelson W., Cain Jr C., Trans. ASME J. Eng. Pr. 82A (1960) 194.

[3] SHIRLEY H.T., J. Iron Steel Inst. London 182 (1956) 144.

[4] REID W.T., External Corrosion and Deposits in Boilers and Gas Turbines (Elsevier, New York, 1971).

[5] Trafford D.N.H., Whittle D.P., Corros. Sci. 20 (1980) 497-509.

[6] Shi L.Q., Zhang Y.S., SHIH S.T., J. Chin. Soc. Corros. Prot. 10 (1990) 135.

[7] Zhang J., ZenG C., Wu W., Prog. Mater. Sci. 6 (1992) 375.

[8] Zeng C., Zhang J., Wu W., J. Chin. Soc. Corros. Prot: 13 (1993) 59.

[9] Wu W., Niu Y., Zhang J., Shen J., J. Chin. Soc. Corros. Prot. 11 (1991) 233. 
[10] Longa Y., Takemoto M., Corrosion Control. Proc. 7th APCCC, International Academic Publishers, Vol. 1 (Beijing, China 1991) p. 64.

[11] Zhang Y.S., Shi L.Q., SHih S.T., J. Chin. Soc. Corros. Prot. 12 (1992) 20.

[12] SHI L.Q., ZHANG Y.S., SHIH S.T., as [10], Vol. 1 (1991) p. 142.

[13] ShiH S.T., Shi L.Q., Zhang Y.S., J. Chin. Soc. Corros. Prot. 12 (1992) 189.

[14] Zhang Y.S., Li X.M., Shi L.Q., ShiH S.T., J. Chin. Soc. Corros. Prot. 11 (1991) 17.

[15] Shi L.Q., Zhang Y.S., SHiH S.T., J. Chin. Soc. Corros. Prot. 12 (1992) 196.

[16] NiU Y., WU W., GuO J., ZHANG Y.S., as [10], Vol. 1 (1991) p. 130.

[17] Zhang Y.S., J. Chin. Soc. Corros. Prot. 12 (1992) 1.

[18] ZHANG Y.S., SHIH S.T., CAO T.L., as [10], Vol. I (1991) p. 124.

[19] Buscaglia V., Nanni P., Bottino C., Corros. Sci. 30 (1990) 327.

[20] Zhang Y.S., Li X.M., CaO T.L., Shih S.T., Corros. Sci. Prot. Tech. 4 (1992) 9.

[21] Zhang J., Niu Y., Wu W., J. Chin. Soc. Corros. Prot. 10 (1990) 207.

[22] NiU Y., M.S. thesis, Inst. Corros. Prot. Metals, Academia Sinica (1989).

[23] Zhang J., Zeng C., Niu Y., Wu W., Corros. Sci. Prot. Tech. 3 (1991) 56t.

[24] WU G.X., Nishikata A., Tsuru T., as [10], Vol. 1 (1991) p. 136. 